\title{
Gender representations in the illustrations of the 6th Grade Language Textbook used in Greek Elementary School
}

\author{
Nikolaos Karintzaidis (Corresponding author) \\ Teacher in Primary Education, 522 00, Argos Orestiko, Greece \\ E-mail: nikolaskarin@gmail.com \\ Anastasia Christodoulou \\ Faculty of Philosophy, Aristotle University of Thessaloniki, 541 24, Thessaloniki, Greece \\ E-mail: nata@itl.auth.gr \\ Argyris Kyridis \\ School of Early Childhood Education, Aristotle University of Thessaloniki, 541 24, Thessaloniki, Greece \\ E-mail: akiridis@nured.auth.gr \\ Ifigeneia Vamvakidou \\ School of Early Childhood Education, University of Western Macedonia, 531 00, Florina, Greece \\ E-mail: ibambak@uowm.gr
}

Doi:10.7575/aiac.alls.v.7n.6p.113

URL: http://dx.doi.org/10.7575/aiac.alls.v.7n.6p.113
Received: 08/08/2016

Accepted: 23/10/2016

\begin{abstract}
This study explores the way in which the two sexes are presented in education and particularly in the illustration of the language textbook used in the 6th Grade of Greek elementary school. In a society where gender equality is constitutionally enshrined and displayed as an educational policy objective, it attempts to examine if school textbook images respond to the demands of social reality, or perpetuate outdated gender stereotyped educational practices. The visual communication system that school textbooks use has the same rhetoric in of the conveyance of ideological and cultural messages as the linguistic system. Therefore, students receive plenty of information from both communication systems about the roles and stereotypes that are considered appropriate for each sex. In the past, several studies have analyzed the linguistic system, while this is the first attempt at an organized and systematic analysis of the visual system in language textbooks, and specifically the one in 6th Grade. Both content analysis, as a measurement technique, and semiotics, as a visual analysis method, were used as a research method. The analysis of data showed that (a) the presentation of the two sexes in the illustration of this language textbook is not objectively compared with social changes, (b) apart from the quantitative inequality that exists in the presentation of the two sexes, there also appears to be a big difference in qualities such as behavioral characteristics, occupations, and activities, and (c) there is a reduction in the representation of outdated gender stereotypes, which is not necessarily positive, as the diversity of roles they undertake in the modern social sphere is not emphasized.
\end{abstract}

Keywords: textbook, illustration, representation, gender roles, stereotypes, semiotics

\section{Introduction}

Equality of educational opportunities for the two sexes has been the focus of many a research project worldwide. According to Turner (1991: 275), gender constitutes a social, economic and cultural structure, is recognized as the basis of social organization, and is equally important as class or race. Gender is not an invariant physical entity, but a product of social and cultural conditions which changes over time, and is divided into biological, which is characterized by biological factors, and social, which is used to describe the social categories of masculinity and femininity, i.e. the characteristics and behavior attributed to each of the sexes, such as occupations, games, household roles, aggression, dependency, domination, sexual partners, gestures, sitting positions, talking styles, etc. (Turner, Abercrombie \& Hill, 1991).

The socialization of gender roles starts from the moment the child is born, within the family, and continues in school. School transfers knowledge and at the same time prepares students for their future roles in society. The values that school imparts on students are values of the dominant ideology and, according to Kantartzi (2003:13), every society can be judged by the content of their school curriculum.

Education was considered by the women's movement as a tool for greater assertion of women's rights, since it could be 
converted from a sphere in which inequality was implemented to a space where one could lobby for social change. This has been pursued through changes both in the statutory curriculum and in the informal interaction of boys and girls, in and out of the classroom (Deligianni-Kouimtzi, 1999: 313-333). Papageorgiou (2004) claims that if we are to change these hierarchical values, i.e. socially imposed superiority, then education and social knowledge must re-socialize individuals and guide them towards a re-awareness of their position.

School textbooks are the product of prevailing, dominant ideology and so their study can deconstruct a society's way of thinking regarding its attitude towards both sexes. A textbook is the most important tool used by teachers and students in the classroom and at home to achieve teaching and learning objectives (Kapsalis \& Charalampous, 2008: 199-204). Thus, textbooks have a significant influence on the ideological cultivation of children and help to more effectively instill established gender stereotypes (Vamvakidou, 2004: 13-19; Vamvakidou \& Gkolia, 2009: 80-94).

There are two views on the acquisition of gender stereotypes and the role they play in the psychological and social adjustment of the individual. On the one hand (Kohlberg, 1966: 82-172), there are those who argue that the adoption of a traditional gender identity is one of the most important tasks of childhood and adolescence, while on the other hand (Block, 1973: 512-526), there are those who support that the traditional views on gender identity restrict personality development, since they oversimplify perceptions and limit life's prospects. The stereotypes of gender roles are associated with the concept of sexism, which refers to a process where people become socialized with the thought of having to act and think in ways appropriate to their sex (Michel, 1986).

According to Apple (2008: 15, 149), through their content and form, school textbooks reflect specific constructions of reality and special ways of collecting and organizing the vast horizon of existing knowledge, which legitimize the culture of certain social groups, what Raymond Williams called selective delivery. But books, besides being cultural products, are also goods for sale. They are designed and written by real people with specific interests within specific structural constraints, as their approval is subject to economic and political dynamics under state supervision. Therefore, textbooks are products of political, economic and cultural activities and compromises, as well as attempts at reconstructing hegemonic control by integrating the knowledge and perceptions of the less powerful groups under the umbrella of the discourse of the dominant groups. The importance of textbooks as regards their socialization function and shaping of attitudes, values and behaviors is thus evident, since knowledge is never neutral and textbooks do not simply convey facts.

A textbook's functions are carried out not only through the texts it contains but also through its visual and pictorial material. At school, students normally learn to read text but not images. Therefore, it is recommended that iconographic literacy become a key objective of elementary schools (van Leeuwen, 1992: 35-58; Mikk, 2000: 300-307). Images enhance aesthetic pleasure and strengthen, unravel, and reinforce the meaning of the text. Text and image are two communication systems operating in parallel and transmitting messages (Barthes, 1983). Images are non-linguistic information carriers and are utilized by students regardless of their reading skills and fluency. The analysis of the image is itself significant. Recent studies (Kress \& van Leeuwen, 1996) have shown that written or spoken language is not the only available way of constructing meaning. But the most important is that the image functions ideologically, communicatively and aesthetically on many levels. Moreover, all the texts and images of language textbooks imperceptibly transmit to the student a code of values, behavior and a certain sense of right and wrong (Kotsalidou, 2003; Vamvakidou, Christodoulou, Vazoura \& Solaki, 2014: 330-353).

This research paper examines if the illustration of the specific textbook being studied conveys gender stereotypes and representations, introducing different roles for the two sexes both in terms of behavior and in terms of a chosen occupation, game or locale.

\section{Methodology}

The methodology used to conduct this research is a combination of two research methods, content analysis as a technique of measurement and semiotics as a visual analysis method. Content analysis is concerned with the description of a text, while semiotics deals with the interpretation of the objective structures. Specifically, the concept of analysis concerns the apparent content of a text, whereas the concept of interpretation is often associated with the text's latent meaning. Content analysis cannot analyze all semiotic systems; instead it focuses on the linguistic. For this reason, it is combined with semiotic analysis to interpret the deeper meaning structures of visual systems contained in language textbooks.

Content analysis correlates the intention of the producer and the quantitative character of semiotic text. The text conceals the producer's interest, which may come to the surface with quantitative measurement methods (Holsti, 1968).

Content analysis is a detailed observation of any communicative material and, according to Mayring (2000), is divided into quantitative and qualitative content analysis. In this paper, we applied the approach of inductive category development. Particularly, after all of the sample images had been collected, the levels of analysis were defined and the images were divided into these categories, leading to some of them being revised and new ones being formulated. Eventually, we settled on the final analysis framework, followed by the final classification and analysis of results.

More specifically, the methodological tool used for the semiotic analysis of the sample images was formed by combining other semiotic analysis tools used by Lagopoulos and Boklund-Lagopoulou $(1980 ; 2012)$ and Christodoulou $(1996 ; 2007)$ in earlier surveys. This tool, however, seeks to examine the semiotic text both in terms of structural semantics (Greimas, 2005) and multimodality (Kress \& van Leeuwen, 2010). It should also be noted that the images' semiotic analysis reports are an essential part of this research. 
After the relevant images were encoded and categorized, two judges - a man and a woman - were asked, after a briefing, to place the reports given to them in the relevant categories, so that intercoder reliability and validity of categorization could be checked. The degree of agreement in the classification of thematic reports was $91 \%$, with $80 \%$ having been set as the lowest limit.

The starting point of this analysis is the determination of the unit of analysis and recording unit. The whole text (item) was used as the unit of analysis; in other words, the image's main message was recorded so that the image could then be encoded in the appropriate category or categories. We must clarify that the analysis takes into account pictures, photos, paintings, sketches, comics, posters, newspapers, magazines and generally any visual representation that contains a gendered figure.

This process ultimately led to the formulation of inductive category development, where the content of the sample images is what determines the categories, and to the precise definition of these categories. Thus, the system's main categories and subcategories were organized as follows:

\section{Gender equality}

Men in stereotypical female roles

Women in contemporary roles

Non-differentiation of behavior/games among boys-girls

\section{Sexism}

\section{Sexism \& role/occupation}

Men in stereotypical roles/occupations

Women in stereotypical roles/occupations

\section{Sexism \& locale}

Men in stereotypical locales

Women in stereotypical locales

\section{Sexism \& games}

Boys in stereotypical behavior/games

Girls in stereotypical behavior/games

The next step in this analysis was the evaluation of the data of the images in order to classify them in the above categories and subcategories. So, initially, all figures were identified in each picture and categorized according to gender. Then the image content was examined semantically and classified in one of the above analytical categories. According to the main conceptual areas of analysis, the research project examines to what extent everyday roles, professional activities, locales and games are linked to the male and female gender. In other words, it is not only the incidence of each category that is examined, but also how each category is structured through the images.

Our main aim being to highlight stereotypical roles in the representations of the two genders, we will find all the characters depicted in the various visual elements found in the school textbook and will classify them into two major categories, namely those who promote gender equality and those who promote sexism, thereby confirming and ratifying the existing social ideological stereotypes. In this way, we will check the incidence of sexist models and will verify the existence or absence of sexism in the book's images. Through semiotic analysis, the semantic codes and analytical categories of each image have been identified and recorded, and we are thus attempting to examine how the (in)evident sexism is constructed through the roles and occupations, locales or games and behavior of the depicted characters.

Encoding was followed by statistical processing (frequency analysis, percentage analysis) using the statistical analysis program SPSS.

\section{Sample}

The sample consists of all the illustrations found in the $6^{\text {th }}$ Grade elementary school language textbooks in use since 2006. Specifically, it comprises the student's book, which has three volumes, and the workbook, which has two volumes. Out of a total of 196 images (student's book, workbook), there are 113 images containing gendered figures for analysis.

\section{Data analysis}

The analysis showed that a total of 418 characters are displayed in the textbook's illustrations. More specifically, as shown in Table 1, there are depictions of 200 (or 47.8\%) men, 104 (or 24.9\%) women, 72 (or 17.2\%) boys and 42 (or $10.1 \%$ ) girls.

The male figures in the textbook's images account for about $1 / 2$ of all the illustrated characters, while the figures of women and children constitute the remaining $1 / 2$. Specifically, the female figures form nearly $1 / 4$ of all the characters and figures of children another $1 / 4$ of the total. Nevertheless, in children's portrayals, too, boys outnumber girls at a ratio of 6 to 4. 
Table 1. Frequency of occurrence of gendered figures

\begin{tabular}{llrr}
\hline \multirow{3}{*}{ Gender } & Man & $\mathrm{n}$ & \multicolumn{1}{c}{$\%$} \\
& Woman & 200 & 47.8 \\
& Boy & 104 & 24.9 \\
& Girl & 72 & 17.2 \\
& Total & 42 & 10.1 \\
& 418 & 100.0 \\
\hline
\end{tabular}

The incidence of gendered characters in the respective units of the language textbook is reflected in Table 2, according to which male characters have the largest incidence in units on war, art and devices. Female figures are more frequently found in units on art, housing and appliances. Boys appear more frequently in the units relating to accidents and life in other places, while girls are to be found more often in units for war and peace and life in other places.

Table 2. Frequency of occurrence of gendered characters in relation to the textbook's units

\begin{tabular}{|c|c|c|c|c|c|c|}
\hline & & \multicolumn{4}{|c|}{ GENDER } & \multirow[t]{2}{*}{ Total } \\
\hline & & Man & Woman & Boy & Girl & \\
\hline \multirow[t]{17}{*}{ UNIT } & Unit 1 & 8 & 0 & 4 & 0 & 12 \\
\hline & Unit 2 & 4 & 12 & 2 & 5 & 23 \\
\hline & Unit 3 & 36 & 12 & 3 & 2 & 53 \\
\hline & Unit 4 & 6 & 1 & 1 & 2 & 10 \\
\hline & Unit 5 & 20 & 7 & 0 & 0 & 27 \\
\hline & Unit 6 & 7 & 5 & 9 & 8 & 29 \\
\hline & Unit 7 & 9 & 10 & 2 & 1 & 22 \\
\hline & Unit 8 & 0 & 0 & 6 & 0 & 6 \\
\hline & Unit 9 & 40 & 24 & 6 & 1 & 71 \\
\hline & Unit 10 & 5 & 3 & 14 & 3 & 25 \\
\hline & Unit 11 & 5 & 3 & 3 & 3 & 14 \\
\hline & Unit 12 & 6 & 1 & 0 & 0 & 7 \\
\hline & Unit 13 & 10 & 3 & 4 & 0 & 17 \\
\hline & Unit 14 & 6 & 5 & 0 & 0 & 11 \\
\hline & Unit 15 & 27 & 15 & 7 & 1 & 50 \\
\hline & Unit 16 & 9 & 1 & 3 & 2 & 15 \\
\hline & Unit 17 & 2 & 2 & 8 & 14 & 26 \\
\hline Total & & 200 & 104 & 72 & 42 & 418 \\
\hline
\end{tabular}

As regards the main categories of analysis, namely gender equality and sexism, Table 3 shows that most of the characters depicted in the book are classified in the category of sexism $(64.8 \%)$, while the category of gender equality follows with a great percentage difference (35.2\%).

If we look at the analytical categories in relation to the gender of the depicted characters, according to Table 3, we will find that the overwhelming majority of male characters appear in the sexism category, i.e. 195 times, as compared to the gender equality category, where they appear 5 times. It is noteworthy that the women and children depicted in the images have a higher incidence in the gender equality category, with 74 women 38 boys and 30 girls portrayed, compared to the 30 women, 34 boys and 12 girls that fall under the sexism category.

Table 3: Frequency of occurrence of analytical categories based on gender

\begin{tabular}{llrrrrr}
\hline & & \multicolumn{2}{c}{ GENDER } & \multicolumn{3}{c}{ Total } \\
& & Man & Woman & Boy & \multicolumn{2}{c}{ Girl } \\
CATEGORY & Sexism & 195 & 30 & 34 & 12 & 271 \\
& Gender equality & 5 & 74 & 38 & 30 & 147 \\
Total & & 200 & 104 & 72 & 42 & 418 \\
\hline
\end{tabular}

The data obtained from the iconographic analysis of the representations of the two genders in the $6^{\text {th }}$ Grade elementary school language textbook has resulted in Summary Table 4, which includes all the categories and subcategories of analysis as to their incidence. In this way it is easy to deduce whether or not sexism and gender discrimination is to be found in the depicted characters. Examining combinatorially the subcategories in terms of gender, we see that these data confirm the research assumptions and are not significantly different from the corresponding data of previous relevant research. 


\begin{tabular}{llcc}
\hline \multirow{2}{*}{ Gender equality } & $\mathbf{1 0 1}$ Men in stereotypical female roles & $\mathrm{N}$ & $\%$ \\
& $\mathbf{1 0 2}$ Women in contemporary roles & 5 & 1.2 \\
& $\begin{array}{l}\mathbf{1 0 3} \text { Non-differentiation of behavior/games } \\
\text { among boys-girls }\end{array}$ & 74 & 17.7 \\
$\begin{array}{l}\text { Sexism \& } \\
\text { role/occupation }\end{array}$ & $\mathbf{2 1 1}$ Men in stereotypical roles/occupations & 195 & 16.3 \\
& 212 Women in stereotypical & 30 & 46.7 \\
Sexism \& locale & roles/occupations & & 7.2 \\
& 221 Men in stereotypical locales & 187 & 44.7 \\
Sexism \& games & $\mathbf{2 2 2}$ Women in stereotypical locales & 20 & 4.8 \\
& $\mathbf{2 3 1}$ Boys in stereotypical behavior/games & 34 & 8.1 \\
& $\mathbf{2 3 2}$ Girls in stereotypical behavior/games & 12 & 2.9 \\
\hline
\end{tabular}

Combining subcategories 101, 211 and 221, we conclude that there are 200 male figures of which 195, or 98\%, seem to have stereotypical roles and occupations, while only 5 , or $2 \%$, are found in traditionally female roles. Of the 195 who have stereotypical roles, 187 are located in stereotypical locales, that is, outside the home, engaged in outdoor work. Similarly, for women, if we combine subcategories 102, 212 and 222, we will see that of the 104 instances, 74 (or $71 \%$ ) appear to have modern roles and occupations, while 30 , or $29 \%$, stereotypically female roles and occupations. Of these, 20 are in stereotypical locales, that is, in the home. Therefore, men do not seem to change their stereotypical roles and occupations by undertaking more "female" roles, while women are those that penetrate more modern roles and occupations.

From the childhood characters portrayed in the language book's illustrations, we can see, by combining subcategories 103, 231 and 232, that there are 72 boys, of which 38 (or 53\%) show no difference in behavior with the girls, while 34 (or 47\%) engage in stereotypical "boyish" behavior. Similarly, for girls we conclude that there are 42 figures, of which 30 (or $71 \%$ ) show no difference in behavior compared with boys, while 12 (or 29\%) engage in stereotypical "girlish" behavior. Therefore, there is a greater expression of gender-based equality in depictions of children, although more boys that demonstrate stereotypical behavior.

Sexism, that seems to be predominant in the male characters depicted in the language textbook, is structured through various analyzed semantic codes that create a rich context of gender discrimination with regard to role or occupation, locale, behavior, character or games. So, apart from the incidence of the relevant aspects, sexism is structured using elements relating to the locale, the role, the occupation and the behavior of the depicted characters.

The locale of the figures is very important, and concerns any occupation within or outside the private sphere of the home. Specifically, of the 200 men, 191 (or 96\%) are presented outdoors, away from home, and only 9 or $4 \%$ indoors. Similarly, out of a total of 104 female figures, 84 (or 81\%) are depicted outdoors, away from home, and only 20 (or $19 \%$ ) indoors. Similar ratios are to be found with the children portrayed, in terms of their locale. More specifically, of the 72 boys, 62 (or 86\%) are depicted outdoors and only 10 (or 14\%) indoors. Of the 42 girls found in the illustrations, 31 (or $74 \%$ ) are outdoors, while 11 (or $26 \%$ ) are indoors.

The depicted characters' apparent roles and occupations are also of great importance, since, depending on their respective gender, these roles and occupations reflect various social stereotypes and ideological beliefs that confirm gender discrimination. Following quantitative processing of the data recorded, it was revealed that there are 107 different occupations and roles represented by the illustrated figures. Regarding the conceptual axis of the categories relating to the occupation or the role of the characters by gender, 61 occupations or roles were shown to involve men, 34 women, 34 boys and 19 girls.

The occupations and roles relating to men and depicted in this language textbook are: actor, appearing 32 times; soldier, appearing 26 times; theater/film director, appearing 14 times; protester, appearing 13 times; presenter, appearing 12 times; journalist and museum visitor, appearing9 times each; father, appearing 8 times; anti-establishment activist, police officer, seafarer and student, appearing 4 times each; farmer, supervisor, combat soldier, immigrant, customer, passerby, devotee, refugee, authority figure, husband, savior, a relaxed person and fisherman, each appearing 3 times; teacher, horseman, driver, priest, grandfather, warlord and skier, appearing twice each; and, finally, athlete, doctor, son, graphic artist, decorator, manager, lawyer, dependent, inventor, hero, spectator, theologian, conqueror, shopkeeper, robber, captain, musician, detective, performer of housework, mountain climber, pedestrian, teaser, waiter, set designer, songwriter, injured individual, traffic cop, lighting technician and mason, appearing once each.

The occupations and roles of women presented in the book's images are: actress, appearing 23 times; housewife, appearing 11 times; mother, appearing 10 times; presenter, appearing 8 times; protester and journalist, appearing 7 times each; farmer, appearing 6 times; soldiers' assistant and devotee, appearing 5 times each; college student, appearing 4 times; rewarder, cook, performer of housework and wife, appearing 3 times each; teacher, makeup artist, immigrant, 
pedestrian and refugee, each appearing twice; and, finally, grandmother, secretary, nationalist, free woman, costume designer, dependent, museum visitor, researcher, traditional woman, client, passerby, set designer, theatre/film director, crossing guard and lighting technician, appearing once each.

The occupations and roles involving boys and presented in the book's pictures are: actor, appearing 7 times; follower of tradition and pedestrian, appearing 6 times each; boy engaged in religious activities and student, each appearing 5 times; injured boy, appearing 4 times; nephew, impatient boy, son, dependent, museum visitor, animal lover and curious boy, appearing 3 times each; spectator, swimmer, sled driver, cyclist and planter, appearing twice each; and, finally, carefree boy, fisherman's helper, hesitant boy, grandson, boy dealing with technology, hero, sad boy, studious boy, boy engaged in naval activities, observer, teaser, stubborn boy, troublemaker, scared boy, happy boy and spearfisherman, appearing once each.

The girlish occupations and roles presented in the language textbook's illustrations are: student, appearing 6 times; girl engaged in religious activities, swimmer and traditional girl, appearing 5 times each; daughter and friend, appearing 3 times each; girl interested in nutrition, dependent, museum visitor, carnival participant, performer of housework, observer, pedestrian and planter, each appearing twice; and, finally, cook's helper, spectator, logical person, writer and scared girl, appearing once each.

The 61 male occupations and roles presented in the illustrations of this language textbook, when compared with the 34 female occupations and roles, show that these images do not provide an objective image of the modern woman, who is engaged in various occupations and roles. In correspondence is also the presentation of the boys with 34 roles/occupations compared with girls who have 19 roles/occupations.

\section{Discussion}

This research of gender representations as illustrated in the $6^{\text {th }}$ Grade language textbooks used in Greek elementary school showed that the books contain different representations of the two genders and, generally speaking, their presentation is not objective when compared with social changes and reality, thus perpetuating social stereotypes and ideological beliefs regarding sex. However, although there is a conscious effort on the part of authors to convey positive messages in support of gender equality, the image analysis of the textbook shows that references to gender equality are rather superficial and do not reflect the authors' deeper perceptions and attitudes.

Books play an important role in the formation of stereotypes for both sexes, according to the most important socialization theories (Kantartzi, 2003). Whatever appears in children's literature and is related to both genders significantly affects gender socialization. In other words, it determines the ideas that children form about what is considered socially acceptable and appropriate for each sex. It further encourages children to imitate the actions of characters of the same sex as them.

Although gender equality is a constitutionally guaranteed right and objective of education policy, as stipulated in educational programs, and is furthermore also the aim of various foundations, such as the General Secretariat for Gender Equality, our semiotic analysis and content analysis show that these books do not apply the principles of gender equality.

Women play an insignificant role in the surveyed textbook, since the representation of the two sexes is discriminatory. The numerical superiority of men is overwhelming, while women appear less frequently. The representation of girls in relation to boys is comparatively better, since it seems that stereotypes are stricter for adults. This numerical superiority of men that appears in almost all units of the book seems to be balanced by the two units on home and life outside the city.

Regarding the occupations and roles of characters illustrated in this textbook, there is a numerical superiority of those associated with men, compared to those linked to women. Thus, there are fewer jobs associated with women than with men, at a ratio of 1:3, whereas in earlier textual analysis surveys, the ratio was 1:6 in Kapetsoni (2015) and 1:7 in Deligianni-Kouimtzi (1987). So men are reflected in a wider variety of occupations than women. More specifically, for men there are various occupations and a wide variety of them, while for women the options are more limited. Men have the monopoly on prestigious occupations offering a certain status and financial standing, while women appear in occupations related exclusively to care, assistance and the arts. Men are presented in activities and occupations that require strength and creative or leadership skills, such as a mason, lawyer, graphic designer, warlord, etc. Only few female figures appear which could be used as role models by both girls and boys, so that they would be able to trust in the quality of female characters. Such examples include the researcher, journalist, presenter, director, and actress, but given the lack of other conventional prestigious female occupations, such as a doctor, lawyer, or manager, they serve more to mislead students about the reality of life than to bolster the professional image of women. Many of the occupations referring to women are linked with women's appearance, such as makeup artists or costume designers. The role given most prominence to for women is that of the housewife and mother who takes care of the family, from housework to nutrition. However, emphasis is also given to man in the role of a father, which reinforces the positive image of man and plays a key role in the education of children and especially of boys. The role of the spouse appears equally in both sexes, but the family structure portrayed is only that of a traditional family involving a man and a woman. However, in reality, children come into daily contact with various modern types of family found in contemporary society, and this may have a negative impact on their psyche as they experience a different reality at home and in their lives than what they see in their textbooks. Generally, the males portrayed seem to be more dynamic than the female characters, which are more passive and have a lower status. Therefore, these images distort everyday 
social reality and statistics (Goldin, 1984), which show that women hold increasingly senior positions with high salaries.

In this textbook's illustrations, there is an attempt to present women engaged in men's activities, entering the male arena and exiting the private and personal sphere of the home. This is something positive which previous textbooks had not succeeded in achieving, according to Kantartzi (1991). On the other hand, men are rarely seen performing women's activities, but are portrayed mainly in family relationships and roles. However, in the public sphere men are the ones who are presented in prestigious positions and having occupations that grant them power and authority, while women, when presented outside the home, have access to limited occupations involving the provision of services, the education of children, the arts and appearance. This broadening of the variety of activities and occupations for women when compared with older textbooks cannot be accounted as a positive aspect of the new textbooks since the stereotypes of a woman's role remain the same, while the real role of modern man is not portrayed.

Stereotypes associated with the male gender remain, such as physical strength (mason), energy (athlete), bravery (soldier), intelligence (manager), creativity (inventor) and generally all those elements that are highly valued in our society. Although stereotypes concerning the role of woman, which want her to be active in the household and be responsible for housework, continue to be evident in the images of this book, there is an attempt to move away from the domestic sphere and to undertake more modern roles and occupations.

Stereotypes of the role and behavior of children have been eliminated completely according to the image analysis conducted, since there is no significant variation in the behavior and games played between boys and girls. The presentation of children's characters is similar to that of adults, but there seems to be equality of representation of their roles. Stereotypes that want boys to be active, restless, teasers, troublemakers and athletic remain and in many pictures these stereotypes are adopted by girls too. So girls appear to be involved in stereotypically boyish activities, but boys never appear to engage in stereotypical girlish behavior. It seems that stereotypes are stronger for boys than for girls, as Kantartzi (1991) has found.

Therefore, the images in these books reflect a sexist mentality that presents men as superior and women as inferior. The distinction between the two genders happens in an indirect manner, given that men appear in interesting roles and a variety of occupations and activities, while the image of women is presented in a fragmented way, with their basic duty still considered to be the role of mother and housewife. These images are internalized by children through the process of socialization and adversely affect the free development of their personality and ideology. The fact is that female stereotypes, which are accepted by society, hardly encourage women to become independent and competitive, while strictly masculine stereotypes exert pressure on the psychology of boys and men to meet society's expectations towards their gender.

In conclusion, the illustration of this book verifies and perpetuates the traditional stereotypical ideology of gender discrimination, namely that men undertake and handle higher and more demanding roles and occupations, while women, despite efforts for them to enter traditionally male activities, remain in the shadow of men and undertake stereotypically female occupations and roles, such as food, care, raising children, etc. On the contrary, there does not seem to be strong gender discrimination in children's images, as both the boy and the girl are presented on an equal basis regarding their behavior and activities.

The need to investigate the way in which patriarchy is reproduced and changes form throughout history and in different cultural contexts resulted in the use of the term "biological/social gender system". On this basis, a different approach was created, according to which capitalism and patriarchy are considered autonomous systems of social relations involving exploitation and power between classes and genders, respectively. Division of labor is the basic (common) tool of the two systems. The method, the conditions and spheres of cooperation, but also of conflict, between the priorities of the two systems are different and equilibria are historically and geographically limited (Vamvakidou, Solaki, \& Papadima, 2016: 45-59).

\section{References}

Anagnostopoulos, D. (1997). Representations of the female and male sex in the texts of the book 'My Language' of Primary Education. In V. Deligianni-Kouimtzi, \& S. Ziogou-Karastergiou (eds.), Gender and School Act (pp.316-330). Thessaloniki: Vanias.

Apple, M. W. (2008). Official Knowledge. (G. Grollios, eds.) Thessaloniki: Epikentro.

Apple, M. W., \& Christian-Smith, L. K. (1991). The Politics of the Textbook. New York: Routledge.

Arnot, M. (2006). Reproducing Gender? Essays on Educational Theory and Feminist Politics. Athens:Metaixmio.

Athanasiadou, Ch. (2002). Young women with a university education and the reconciliation of private and public sphere in adulthood design. Unpublished PhD Thesis, Aristotle University of Thessaloniki, Department of Psychology.

Augoustinos, M., \& Walker, I. (1995). Social Cognition: An Integrated Introduction. London: Sage.

Bandura, A. (1977). Social Learning Theory. Englewood Cliffs: Prentice Hall.

Bandura, A., \& Huston A. (1961). Identification as a process of incidental learning. Journal of Abnormal and Social Psychology, pp. 311-318. 
Barthes, R. (1979). Mythologies. (K. Chatzidimou, \& I. Ralli, trans.) Athens: Kedros.

Barthes, R. (1983). Image - Music - Text. (M. Grigoriou, trans.) Athens:Plethron.

Barthes, R. (2014). Elements of Semiology. (Ch. Magoulas, trans.) Trikala: Epekeina.

Beauvoir, S. (2008). The Second Sex. (T. Konstantinou, trans.) Athens: Metaixmio.

Belsky, J. (1979). Mother-father-infant interaction: Anaturalistic observational study. Development Psychology , 15 (6), pp. 601-607.

Berger, J. (2011). Ways of Seeing. (E. Stamatopoulou, trans.) Athens: Metaixmio.

Berelson, B. (1952). Content Analysis in Communication Research. New York: Hafner Press.

Block, J. (1973). Conceptions of sex role: some crosscultural and longitudinal perspectives. American Psychologist , 28, pp. 512-526.

Boklund-Lagopoulou, K. (1980). Semiotics and Society. International Conference of the Greek Society of Semiotics (pp. 7-18). Thessaloniki: Odisseas.

Boklund-Lagopoulou, K. (1983, Jun 15). What is Semiotics?. Diavazo , pp. 15-23.

Bryson, V. (2005). Feminist political theory: An introduction. (E. Panagou, trans.) Athens: Metaixmio.

Chandler, D. (1994). Semiotics for Beginners. [Online] Available: http://visual-memory.co.uk/daniel/Documents/S4B/ (January 18, 2016).

Chandler, D. (1998). Notes on The Gaze. [Online] Available: visualmemory.co.uk/daniel/Documents/gaze/greek/gaze_greek.html (January 20, 2016).

Charalampopoulos, V. (2006). The teaching approach of the language course with the new language book for elementary school. Thessaloniki: Workshop of the Pedagogical Group.

Christodoulou, A. (1996). Semiotics and Advertising. Efarmosmeni Glossologia , pp. 51-62.

Christodoulou, A. (2007). Semiotics and School Textbooks. Thessaloniki: University Studio Press.

Christodoulou, A. (2012). Paideia, Education, Values: Semiotic Approach. Thessaloniki: University Studio Press.

Cohen, L., \& Manion, L. (1997). Research Methods in Education. Athens: Ekfrasi.

Cohen, S., \& Comiskey, T. (1977). Child Development: Contemporary Perspectives. Illinois: Peacock.

Creswell, J. W. (2011). Educational Research: Planning, Conducting, and Evaluating Quantitative and Qualitative Research. Athens: Iwn.

Dagtoglou, P. D. (2012). Constitutional Law: Civil Rights. Athens-Thessaloniki: Sakkoulas.

Deligianni-Kouimtzi, V. (1987). The stereotypes about gender roles in textbooks of primary school "My Language". Philologos , 49, pp. 229-248.

Deligianni-Kouimtzi, V. (1999). «Our fault...»: The «reason» of gender relations in the context of the problem of citizenship. In Diotima, Center for Women Studies and Research (ed.), The sex of rights (pp. 313-333). Athens: Nefeli.

Devine, P. G. (1989). Stereotypes and prejudice: Their automatic and controlled components. Journal of Personality and Social Psychology, 56 (1), pp. 5-18.

Diakogeorgiou, A. (2012). The illustration of Anthology "With Logic and Dream". Educational Sciences , 3, pp. 137172.

Dimitropoulos, A. (2004). Lectures of Constitutional Law III - Constitutional Rights. Athens: Sakkoulas.

Dragona, T. (2007). Stereotypes and Prejudices. Athens: YPEPTH, University of Athens.

Duberman, L. (1975). Gender and Sex in Society. New York: Praeger.

Eccles, J. S., Jacobs, J. E., \& Harold, R. D. (1990). Gender Role Stereotypes, Expectancy Effects, and Parents' Socialization of Gender Differences. Journal of Social Issues , 46 (2), pp. 183-201.

Eco, U. (1989). A Theory of Semiotics. (E. Kallifatidi, trans.) Athens: Gnosi.

Fiske, J., \& Hartley, J. (2010). The Language of Television. (R. Astrinaki, trans.) Athens: Aigokeros.

Fragkoudaki, A. (1979). The textbooks of primary school. Ideological coercion and violence pedagogy. Athens: Themelio.

Freiderikou, A. (1995). Jenny behind the glass: Representation of gender in language teaching textbooks of primary school. Athens: Ellinika Grammata.

Gavey, N. (1989). Feminist Poststructuralism and Discourse Analysis: Contributions to Feminist Psychology. Psychology of Women Quarterly, pp. 459-475.

Georgiou-Nilsen, M. (1980). The family in the textbooks of primary school. Athens: Kedros.

Giotopoulou-Maragkopoulou, A. $(1998,4)$. The historical shift of the State Council to real equality. Comment on decisions 1933/1988 and 1917-1929/1998. ToS, p. 774. 
Gkotovos, A. (1986). The logic of real school. Athens: Modern Education.

Goldin, C. (1984). The Historical Evolution of Female Earnings Functions and Occupations. Explorations in Economic History, 21(1), pp. 1-27.

Golombok, S., \& Fivush, R. (1994). Gender Development. Cambridge: Cambridge University Press.

Greimas, A. J. (2005). Structural Semantics: An Attempt at a Method. (G. Parisis, trans.) Athens: Patakis.

Hartley, J. (1982). Understanding News. London: Methuen.

Holsti, O. (1968). Content Analysis. In A. Aronson, \& E. Lindzey (eds.), The Handbook of Social Psychology (Vol. 2). London: Addison Wesley.

Igglesi, C. (1990). Faces of women, Masks of Consciousness. Athens: Odisseas.

Kanatsouli, M. (1997). Types of women and women's "voices" in the books of primary school. In V. DeligianniKouimtzi, \& S. Ziogou-Karastergiou (ed.), Sex and School Practice (pp. 303-315). Thessaloniki: Vanias.

Kantartzi, E. (1987). The curriculum and the parameters intervening in the syntax. Modern Education, p. 100.

Kantartzi, E. (1991). The Image of Woman. Diachronic Research of School Textbooks of Primary School. Thessaloniki: Kyriakidis.

Kantartzi, E. (1992). The hidden curriculum and stereotypes imposed on gender roles. Proceedings of Conference "Health and Quality of Life", (p. 108). Athens.

Kantartzi, E. (2002). Historical overview in illustration of children's and school books. Thessaloniki: Kyriakidis.

Kantartzi, E. (2003). Stereotypes of gender roles in textbooks of primary school. Thessaloniki: Kyriakidis.

Kapetsonis, K. (2015). Representations of gender in the books of language course of the primary school. Unpublished Master Thesis, Aristotle University of Thessaloniki, Department of Education.

Kapsalis, A., \& Charalampous, D. (2008). School textbooks: Institutional development and modern problems. Athens: Metaixmio.

Kapsomenos, E. G. (2014). Narratology: Theory and methods of analysis of narrative prose. Athens: Patakis.

Kohlberg, L. (1966). A Cognitive-Developmental Analysis of Children's Sex-Role Concepts and Attitudes. In E. E. Maccoby, The Development of Sex Differences (pp. 82-172). Stanford: Stanford University Press.

Kokogiannis, K. (2008). Feminist Pedagogy. Thessaloniki: Kyriakidis.

Kotsalidou, E. (2003). The ideology through the language textbooks of primary school. Education Issues (12), pp. 2339.

Kress, G., \& van Leeuwen, T. (1996). Reading Images: The Grammar of Visual Design. (G. Kourmentala, trans.) Thessaloniki: Epikentro.

Lagopoulos, A.-P. (2004). Epistemology of meaning, structuralism and semiotics. Thessaloniki: Paratiritis.

Lagopoulos, A. P., \& Boklund-Lagopoulou, K. (2012). Introducting semiotics. (I. Vamvakidou, E. Kourdis, \& A. Christodoulou, eds.) Thessaloniki: University Studio Press.

van Leeuwen, T. (1992). The Schoolbook as a Multimodal Text. Internationale Schulbuchforschung, 14 (1), pp. $35-58$.

Levin, J. R., \& Mayer, R. E. (2009). Understanding Illustrations in Text. In B. K. Britton, A. Woodward, \& M. Binkley (ed.), Learning From Textbooks: theory and practice (pp. 95-113). New York: Routledge.

Lips, H. (1988). Sex and Gender: An Introduction. California: Mayfield.

Louvrou, E. (1994). The sexist profile of textbook "My Language" of primary school: linguistic analysis. Glwssa , 32, pp. 45-61.

Maragkoudaki, E. (2000). Education and gender discrimination. Athens: Odisseas.

Markantoni, I., \& Riga, A. (1991). Family, motherhood, sponsorship. Athens: Mauromatis.

Matsaggouras, H. (2006). School Textbooks: Critical assessment of knowledge, teaching and learning process. Comparative and international educational inspection, 7, pp. 60-92.

Maurousoudi, H. (2007). The gendered mode of school textbooks: a study case of the new textbook of 1st Grade of primary school. Unpublished Diploma Thesis, University of Western Macedonia, Department of Preschool.

Mayring, P. (2000). Qualitative Content Analysis. Forum Qualitative Sozialforschung / Forum: Qualitative Social Research (Online Journal), 1 (2).

Mead, M. (1977). Growing up in New Guinea. Harmondsworth: Penguin Books.

Measor, L., \& Siker, P. (1992). Gender and Schools. Gr. Br.: Cassel.

Michel, A. (1981). Sociology of the family and marriage: Basic elements for Greek family. Athens: Gutenberg.

Michel, A. (1986). Down with Stereotypes! Eliminating Sexism from Children's Literature and School Textbooks. Unesco. 
Mikk, J. (2000). Textbook: Research and Writing. Frankfurt: Lang.

Mpamplekou, Z. (1997). The formation of the notion of gender roles: changes in the theoretical stage. Modern Education: Quarterly Review of Educational Affairs , pp. 89-95.

Mponidis, K. (1998). Research issues of contexts of textbooks: National self-stereotypes and hetero-stereotypes in illustration of textbooks "My Language" of primary school. Proceedings of the National Conference on: Greek pedagogical and educational research (pp. 239-246). Athens: Atrapos.

Mponidis, K. (2004). The content of the school textbook as a subject of research: Diachronic review of research and methodological approaches. Athens: Metaixmio.

Nasiakou, M. (1982). Psychology Today. Athens: Papazisis.

Papageorgiou, G. (2004). Hegemony and Feminism. Athens: Tupothito.

Propp, V. J. (1991). Morphology of the Folktale. (A. Parisi, trans.) Athens: Kardamitsa.

Rasinski, K., Crocker, J., \& Hastle, R. (1985). Another look at sex stereotypes and social judgments: an analysis of the social perceiver's use of subjective probabilities. Journal of Personality and Social Psychology, 49 (2), pp. $317-326$.

Rosenberg, G., \& Sutton-Smith, B. (1959). The Measurement of Masculinity and Femininity in Children. Child Development, pp. 373-380.

Saussure, F. (1979). Course in General Linguistic. (P. D. Apostolopoulou, trans.) Athens: Papazisis.

Shrewsbury, C. M. (1987). What Is Feminist Pedagogy? Women's Studies Quarterly, pp. 6-14.

Skinner, B. (1953). Science and Human Behavior. New York: The Free Press.

Spender, D., \& Sarah, E. (1980). Learning to Lose: Sexism and Education. London: The Women's Press.

Stratigaki, M. (2010-2013). National Program for Substantive Equality. Athens: General Secretariat for Equality.

Tatsis, I. (1991). Sociology, vol II. Athens: Odisseas.

Tong, R. (1995). Feminist Thought. A Comprehensive Introduction. London: Routledge.

Tsaousis, D. (1985). The human society: Introduction to Sociology. Athens: Gutenberg.

Turner, B., Abercrombie, N., \& Hill, S. (1991). Dictionary of Sociology. (S. Kantas, \& A. Kantas, trans.) Athens: Patakis.

Tzampazi, F., Kyridis, A., \& Christodoulou, A. (2013). 'What Will I Be When I Grow up?' International Journal of Social Science Research, 1(1), pp. 19-38

Vamvakidou, I. (2004). Gendered narratives and readings of Macedonian Struggle through the historical evidence: gender suppression in the historical action. Filippos, 145, 13-19.

Vamvakidou, I., Christodoulou, A., Vazoura, Z., \& Solaki, A. (2014). Childhood representations in school history textbook of 3rd Grade of high school. Proceedings of Panhellenic Conference with International Participation: Rethinking on childhood (pp. 330-353). Thessaloniki: Zygos.

Vamvakidou, I., \& Gkolia, P. (2009). The representations of woman in illustration: school textbooks of Modern Greek History of primary school. Modern Education , 159, 80-94.

Vamvakidou, I., Solaki, A., \& Papadima, A. (2016). Gendered representations of the First World War, the suffragettes return. In S. Koniordos (eds.), Proceedings of the 5th Panhellenic Congress of Sociology (pp. 45-59). Athens: Greek Sociology Society.

Varika, E. (2009). For a political grammar of gender. Athens: Plethron.

Ziogou-Karastergiou, S., \& Deligianni-Kouimtzi, V. (1981). The stereotype of gender roles in textbooks of primary school. Philologos , 23, pp. 282-295. 